\title{
Interleukin-1-related cytokines as potential biomarkers in autoinflammatory skin diseases
}

\author{
H Bonnekoh", M Maurer, K Krause \\ From 8th International Congress of Familial Mediterranean Fever and Systemic Autoinflammatory Diseases \\ Dresden, Germany. 30 September - 3 October 2015
}

\section{Introduction}

Urticarial rash is a hallmark symptom of autoinflammatory diseases such as Cryopyrin-associated periodic syndrome (CAPS) and Schnitzler's syndrome (SchS). Clinically, the urticarial rash may not be distinguished from the skin symptoms in chronic urticaria patients. As interleukin-1ß (IL-1ß) has been shown to play a pivotal role in the pathogenesis of CAPS and SchS we here aim at investigating IL- $1 ß$ and related cytokines for their potential as diagnostic skin biomarkers in patients with urticarial autoinflammatory syndromes.

\section{Materials and methods}

Immunohistochemical stainings (neutrophil marker myeloperoxidase (MPO), IL-1ß, IL-6, IL-18) from lesional skin of patients with CAPS $(n=3), \operatorname{SchS}(n=9)$ and chronic spontaneous urticaria $(\mathrm{csU})(\mathrm{n}=10)$ as well as healthy control skin samples $(n=10)$ were analyzed by quantitative histomorphometry and compared with cytokine protein concentrations assessed by ELISA.

\section{Results}

Quantitative histomorphometry revealed a higher percentage of neutrophil-dominated dermal cell infiltrate in autoinflammatory diseases that was significant for SchS skin samples as compared with csU samples and healthy controls $(\mathrm{p} \leq 0.05)$. Analysis of IL-1ß, IL-6 and IL-18 positive cells in CAPS and SchS skin showed higher cell numbers which were much less pronounced in $\mathrm{cs} U$ and healthy control samples. In addition, protein concentrations of all three cytokines were significantly higher in autoinflammatory diseases as compared with csU patients and healthy controls $(\mathrm{p} \leq 0.05)$. \section{Germany \\ () Biomed Central}

Charité - Universitätsmedizin Berlin, Dermatology and Allergy, Berlin,

(c) 2015 Bonnekoh et al. This is an Open Access article distributed under the terms of the Creative Commons Attribution License (http://creativecommons.org/licenses/by/4.0), which permits unrestricted use, distribution, and reproduction in any medium, provided the original work is properly cited. The Creative Commons Public Domain Dedication waiver (http://creativecommons.org/ publicdomain/zero/1.0/) applies to the data made available in this article, unless otherwise stated.

\section{Conclusion}

Our study confirms the predominance of neutrophildominated cell infiltrates and demonstrates an upregulation of IL-1-related cytokines in the skin of urticarial autoinflammatory diseases. We suggest to further explore these cytokines as diagnostic biomarkers in larger patient samples.

Published: 28 September 2015

doi:10.1186/1546-0096-13-S1-P197

Cite this article as: Bonnekoh et al:: Interleukin-1-related cytokines as potential biomarkers in autoinflammatory skin diseases. Pediatric Rheumatology 2015 13(Suppl 1):P197.
Submit your next manuscript to BioMed Central and take full advantage of:

- Convenient online submission

- Thorough peer review

- No space constraints or color figure charges

- Immediate publication on acceptance

- Inclusion in PubMed, CAS, Scopus and Google Scholar

- Research which is freely available for redistribution 